\title{
PROBLEMS OF INSTABILITY OF THE WORLD ECONOMY UNDER GLOBALIZATION
}

\author{
Tomasz Dołęgowski \\ Warsaw School of Economics, Poland \\ Serhii Hushko \\ Volodymyr Kulishov \\ Polonia University, Poland
}

\begin{abstract}
We examine the main trends of world economic development. The characteristic feature of the modern world is the acceleration of globalization development, caused by the achievements of scientific and technological progress. The increase in possibilities of global problem solving is accompanied by their exacerbation and degree of openness of public systems in conditions of modern globalization. We consider the interaction of international economic agents, the formation of interconnections, the inevitability of transition to a new and more progressive model of economic development - metaeconomy and the problems which are potentially able to cause negative consequences of the financial sector redistribution. There is a growth of social inequality in the world, resulting in increasing income disparities, which intensifies the migration process and thereby creates new problems as a result of the coexistence of people belonging to different civilizations, cultures and value systems.
\end{abstract}

Keywords: globalization, international economic, transformation, financialization, metaeconomy, paradigm, deindustrialization, migration.

\section{Introduction}

The processes of globalization in terms of instability in the world economy are perceived and evaluated differently. Not only individual scientists, specialists and experts, but also ordinary citizens of different countries regard them differentially. Globalization processes are often perceived in developed countries and cause serious concerns in the developing world. This is due to the fact that the benefits of globalization are distributed unequally. Therefore, one of the main issues that causes the biggest discussion is to determine who stands to gain from globalization. Modern globalization processes expand primarily between industrialized countries and only secondarily embrace developing countries. Globalization strengthens the positions of the first group of countries and gives them additional benefits. At the same time, the expansion of 
globalization processes within contemporary international division of labour is able to freeze the current position of less developed countries of the so-called "world periphery", which are becoming rather the objects than the subjects of globalization.

The modern world is undergoing an unstable, transitional condition and is approaching the crossroads which will lead either to the transformation of the existing unipolar unfair world into a fair multipolar one or to the collision of the poverty with the wealth, collision of western civilization, which covers all other world countries, with other civilizations and destruction of the world (Yatsenko, Kiptenko, Smal, 2012). This means that theoretical science cannot remain aside the issues which arise in the global interdependent world. Globalization in its present version leads to "reformatting" the structure of the modern world, and as a result - the adjustment of national systems of public business activities, changes in strategies of economic, political and spiritual development, which generate a continuous interdependence of the world, which is the basis for its functioning. The growing interdependence unifies and standardizes conditions and factors of the development of individual countries and constitutes the peculiar indicator which determines the level of sustainability of national states and consequently their capacity to deal with the challenges of globalization processes, which today are the main criterion for the consolidation of states in the relevant global or regional structure (Kulishov, 2014).

The majority of modern research studies are aimed at studying the original results of the globalization process, while the background, causes, issues and implications of globalization are still covered insufficiently. That is why the research of the problem of the world economy in a global environment in terms of its instability is relevant (Pacek, 2009).

The purpose of the present paper is to research the nature and manifestation of globalization problems, the direction of global economic development, caused by globalization, also to identify alternative theoretical concepts of globalization, transform the world and national economy, reform the structure of the modern world and define causes of aggravation of global problems.

\section{Problems and challenges of the global economy in terms of its instability}

Due to uneven distribution of the benefits from globalization, the negative consequences of globalization in a particular country will definitely depend on the position this country occupies in the global economy. In this regard, we distinguish three groups of threats, dangers and potential problems which arise at the present stage of economic activity internationalization, depending on which countries they may spread to. First of all, let us distinguish the existing dangers of globalization for all countries, which later can potentially occur in 
less developed ones. Under globalization the destructive influence of centrifugal forces associated with this process is quite possible. As a result, it can cause the breakdown of traditional domestic relations, degradation of uncompetitive industries, worsening of social problems, and aggressive penetration of dissimilar and even hostile ideas, values and behaviour patterns into the society. There are basic problems which nowadays are potentially able to cause negative consequences of globalization in all countries:

- uneven distribution of the benefits from globalization in terms of individual industries of a national economy;

- possibility of de-industrialization of national economies;

- possibility of transferring the control over the economy of some countries from sovereign governments to other hands, including more powerful states, multinational corporations or international organizations;

- possibility of destabilizing the financial sector - financialization, which reflects the dramatic shifts in the structure of the modern world economy concerning the exaggerated dominance of the financial sector;

- potential regional or global instability due to the worldwide interdependence of national economies. Local economic fluctuations and crises in one country may cause regional or even global consequences (Kulishov, 2014).

Less developed countries which belong to the so-called "world periphery" may feel the most negative consequences of globalization. The bulk of them being engaged in internationalization as suppliers of raw materials and producers of labour-intensive products (while some of them are the suppliers of parts and components for modern complex equipment), are fully dependent on leading countries and have smaller and highly unstable revenue.

In addition, in this exchange, any country may incur losses in the first place, due to the reduced price for its goods and services, and in the second place, as a result of the debased exchange rate of its currency relative to the currency in which the commercial transaction was conducted.

The tendency of the emergence within the world financialization of the phenomenon when external debts of the countries are growing, promotes active participation of fringe countries in globalization processes. In this context it should be noted that the aggravation of debt crises in Europe, which began in the summer of 2010, was a turning point and the beginning of "the end of indebtedness era for Western democracies", followed by, firstly, the period of limitation; secondly, structural reforms; thirdly, the search for new revenue sources and markets (Gregosz, 2012). 
Tastes and preferences of consumers from different nations are beginning to change towards the certain global norm and thus contribute to the formation of the global market.

According to prominent scientist Toffler (2008), the market is beginning to lose its traditional normative dominant feature. It is beginning to deny itself. Preserving the market status, these structures simultaneously devaluate their basic characteristics and acquire the features of transfer market formations and a modern economy - metaeconomy.

As we understand it, a metaeconomy - is the beginning of real postindustrial economic relations in their system maturity. A metaeconomy is the beginning of a mature post-industrial economic system, the logical product of the information revolution, which is only starting to spread its values. It is the component of a global synergistic society, the economy of creative work, the economy of production, distribution and consumption of knowledge, the economy of a true humanism era.

Drawing from the logic of general historical transformations, it is necessary to focus attention on the fact that a metaeconomy is not the economy, which is parallel to the market but is the continuation of the market, self-denial of the market with maintenance of its viable perspective achievements. Therefore it is the economy which is de facto no longer a market one. At the same time, a metaeconomy is the bridge not only to a transmarket economy, but also to transmarket civilization. "Under the term "transmarket" we mean the technology of civilization which depends on the market, but is no longer absorbed by the need to build, expand, develop and integrate this structure; the civilization, able to put on the agenda new tasks, as the market is already built". "Now when the main task to build the market is almost complete, enormous energy, which previously was aimed at the creation of the worldwide market system, could be used for other purposes", - said the scientist Toffler (2008).

To oppose such global challenges, the state should have an active control system, implement its own geopolitical development strategy, protect its sovereignty to the maximum, take its bearings in global environment and, what is most important, possess effective mechanisms of influence on economic processes.

The globalization factors in transformation of the current models of economic development are objective economic, social, cultural, scientific, technological, political processes, etc. The formation of a knowledge society; the worldwide spread of democracy and other institutions of civil society; strengthening of the role and capacity of international and supranational regulation mechanisms to influence the development of national economies; internationalization of scientific and technological progress significantly influences the formation of national economies. 
Defining a national economic model should systematically embrace the positions presented above. Therefore we propose to consider the national economic model as a complex theoretical and methodological system which reflects the effect of certain regularities of a particular (modern) stage of the economic development of the state, which is able to provide a high level of prosperity, safe, self-sufficient and competitive development through the effective implementation of economic policy, taking into account endogenous and globalization factors of development.

Thus, at the current stage of global economic development, the national economic models are affected by a complex set of exogenous and endogenous factors. Determination of new theoretical and methodological foundations of modern transformations implies, above all, taking into account some globalization aspects and the development of mechanisms of organic adaptation and interaction between key components of national economic models and institutions for global development. The use of this systematic approach will become a precondition for the effective implementation of the national economic model and achievement of the goal of social development (Kulishov, 2011).

The vast majority of research approaches are aimed at identifying the nature of the impact of globalization a process introduced by various objective and subjective factors which significantly alter the global world, more and more encouraging this or that country to fit into the new conditions of existence in order to have success in production and sale in international markets.

We believe that cyclical trends in the global economy that we observe today indicate that when national economies have economic and resource stability, they will become more adapted to the relevant conditions and will have a stronger national economy than those countries which operate in the global economy.

Uneven distribution of the benefits from globalization occurs not only in individual countries but also in the context of individual industries. And it makes an essential problem. Industries which receive benefits from foreign trade and industries related to export experience a greater influx of capital and skilled labour forces than a number of industries which lose much from globalization processes, losing its competitive advantages due to the increase of market openness. Such industries have to make additional efforts to adapt to economic conditions varying not in their favour. They experience an outflow of capital and job cuts. People lose their jobs, have to look for new ones and sometimes need retraining: all that results in great social expenditures, and what is more, in a short space of time. Consequently, the redistribution of labour forces in view of great social expenditures is inevitable. 
Many research studies see a threat in the de-industrialization of the economy, as globalization processes are associated with the employment reduction in manufacturing industries both in Europe and the USA. Deindustrialization is the cause of the emergence of depressed regions since it reinforces social stratification of society. In fact, some part of manufacturing industries in the economy of industrialized countries is sharply reduced, but it should be noted that this reduction is exceeded by the rapid growth of the share of the service industry, including the financial sector. Deindustrialization is a common phenomenon generated by technological progress and economic development, which is not the result of globalization, though it proceeds parallelly.

This testifies that under globalization of market relations, the importance of the development issues of certain economic regions increases. For example, in Ukraine regional aspects of economic relations have been ignored for a long time, although they play a crucial role in the socio-economic transformations. It is confirmed by the course towards decentralization pursued by the Ukrainian government which binds as much as possible the solution of many issues of legal, organizational, financial, resource and methodological character, i.e. the formation and functioning of a new paradigm of relations within the region. In these circumstances, decentralization policy should be aimed at creating conditions for increasing the regional competitiveness as the basis of dynamic development of the country. In this regard, the re-orientation of the economy of regions to an innovative development model is necessary. The main strategic resources and key factors of economic growth in the regions are structural changes, processes, reforms and human potential, with which regions are entirely able to regulate the existing potential which, as a result, will allow maximizing the contribution to the national economy, providing the increase of competitive advantages in regional, national and world markets.

Reforming the state of regions in Ukraine should be based on positive experience of developed European countries and implementation of European standards of decentralization, taking into consideration their own national peculiarities of the functioning of regions that will help to prevent many errors, reduce material expenditures and time as well as optimize its own algorithm for implementation of reforms.

Economic relations within the regions are the most dynamic and simultaneously poorly regulated processes. The penetration of commoditymoney relations in all spheres of society requires a mechanism which is able to influence the relationships and dependences arising at the regional level, and above all, at individual consumer markets (Padalka, Kulishov, 2015).

Considering the reasons for aggravation of global problems, we can single out a complex of connections and relationships between states and social 
systems, between society and nature on the global scale, which affect vital interests of all nations and countries and can be solved through their joint interaction. Various global issues are closely related. It means that all countries in the modern world are interdependent.

It is determined that among the causes of globalization, the preference should be given to the following:

- innovation progress - it accounts for the impact of scientific and technological progress on the economy. The acceleration and reduction of transportation and means of communication have led to the effect of "the world's contraction" and the reduction of a certain conventional distance (the distance which is expressed in units of time necessary for its overcoming or in the cost price of transportation) between different geographic features. In addition, the development and improvement of communication means enabled the rise of international business to the new level;

- transnationalization of companies - in the context of globalization, it should be emphasized that the transnationalization of companies is one of the key causes of globalization, as it allows companies, on the one hand, to receive additional excess profits, thus contributing to the concentration of capital and monopolization of relevant industries, and on the other, to bypass some government restrictions, transferring conflicts from the intergovernmental level to the intercompany one. Transnationalization is a process of creation of a single international economic space with its common iterative aspects in consumption, production, exchange, ethics, functioning of institutions, etc.;

- $\quad$ standardization of markets and formation of a mega-society - the importance of standardization of markets and industries in different countries cannot be underestimated, since it reduces the level of cultural and other differences among countries, eliminating one of the most important obstacles on the way up to the development of international business;

- globalization of the shadow economy - one of the reasons for inevitable "official" globalization is the existence of the shadow economy, globalization of which nowadays is obvious. We mean not only purely criminal types of activities, the concept of "borders" for which in many spheres (for example, drug trafficking) implies only some additional complications for transportation and therefore a rise in price for goods, but also quite a legal trade, which in the presence of trade barriers turns into smuggling. That is why the efforts of individual states are not enough to counteract this trespassing. Thus, it 
is necessary to create supranational structures, subdue natural processes of globalization and direct them into a civilized channel.

Many experts consider the rise in unemployment to be one of the biggest threats of globalization. They sometimes give a very pessimistic estimation and forecast. As an example of such a forecast, we can quote the statement from the quite famous in the Western world book, written by Hans-Peter Martin and Harald Schumann, the editors of the weekly magazine "Der Spiegel" "The Globalization Trap: The Attack on Democracy and Prosperity“. It is predicted that $20 \%$ of the population will be enough for the world economy to function in this century. We won't require more labour force than that. One fifth of all job seekers will be enough for the production of essential goods and provision of all expensive services, which the world community will be able to afford. These $20 \%$ in any country will be involved in the society life and will earn and consume enough. About $1 \%$ of those who, for example, will inherit a lot of money can be probably added to them. Those $80 \%$, who will find themselves out of work, will have enormous problems. All that means that we are going to have economic and social perturbations of unprecedented size (Martin, HansPeter/Harald Schumann, 1997).

Potential growth of unemployment is possible, in our opinion as a result of shifting by companies of the countries with high cost of labour force of the part of their productive capacity to the countries with low cost of labour force. Export of jobs may turn out to be undesirable for the economies of some states. But most of all in such circumstances, the companies of developed countries will stop the production of loss-making products to switch to the production of the commodity requiring the use of highly qualified personnel. There will be a redistribution of the workforce. As a result, workers with a lower qualification will be left uncalled, their incomes will fall and there will be an increase of unemployment in their environment. So, as a negative consequence of globalization, we mark the increase of the gap in wages between skilled and less skilled workers.

Another threat is connected with the mobility of a labour force. Mass population shift that assumes global character turns to be a serious source of aggravation of the socio-economic situation in the world. Destabilizing factors include new forms of employment (individualization of employment terms, temporary contracts) and globalization of the labour market. The negative effects of the labour movement have been recognized as a potential danger for a long time, and today in many countries it is considered to be quite real. Therefore, nearly all states have introduced these or those forms of control over free movement of labour. They can be particularly perceived in Germany, France, Hungary, etc. However, it should be noted that the most prepared workforce that is of high value, is more mobile and able to find its market niche 
effectively. Under globalization all countries will try to attract talented and skilled workers, willingly giving them visas and offering places in their market. Oversupply of labour forces will result in the global rise of productivity, as the optimum in the labour division will be reached.

One of the problems of globalization is a potential global instability due to the interdependence of national economies worldwide. As a result, local economic crises may have regional or even global implications. This possibility is not theoretical but quite a real one. That is confirmed by the Asian financial crisis which began in the summer of 1997 in Thailand and especially the Great Recession which began in 2008 and is in progress up to now.

Negative aspects of contemporary globalization should be connected with potential conflicts, the probability of which is not excluded, though can be mitigated by the way of developing global cooperation based on political agreements or creation of new international institutions.

\section{Conclusion}

The modern world is transitional. In times when more and more countries experience the extension of economic activity, we have to find new models of development associated with the rejection from the unipolar world and its current western neoliberal model of globalization, resulting in the transformation of the unipolar world for the benefit of humanity into the multipolar one.

Globalization promotes reorganization of the modern world structure, deepening of specialization and international division of labour. In its terms resources are divided more efficiently. International exchange of innovative technologies promotes the increase of the average standard of living and expands life prospects for the population, providing the transition from theoretical to practical bases for the creation of a modern economy metaeconomy, determining key globalization factors in the transformation of current models of economic development.

So, what does globalization mean for countries in the end - a threat or new opportunities? It is almost impossible to answer this question unambiguously, because the balance of positive and negative effects is constantly changing. However, the reality is that globalization represents a completely objective and inevitable phenomenon of our time, which can be slowed down by means of economic policy (which happens in some cases), but cannot be stopped or 'cancelled', because it is an imperative demand of modern society and scientific and technological progress. The process of globalization which has been most active during the latest two decades hides in itself a lot of ambiguities and contradictions, and has become the subject of fierce disputes in the academic and business circles of the world. 
Tomasz Dołegowski, Serhii Hushko, Volodymyr Kulishov. Problems of Instability of the World Economy Under Globalization

\section{References}

Gregosz, D. (2012). Economic Megatrends up to 2020. What can we expect in the forthcoming years? Facts and Findings №106, August 2012. - Konrad-AdenauerStiftung, 2012. - P.3.

Ikenberry, G. J., Kennedy, P. (2002). Global Trends and Global Governance. Foreign Affairs, 81(3), 161. doi:10.2307/20033183

Llussá, F., Tavares, J. (n.d.). Economics and Terrorism: What We Know, What We Should Know, and the Data We Need. Terrorism, Economic Development, and Political Openness, 233-254. doi:10.1017/cbo9780511754388.009

Kulishov, V. (2014). Current Globalization Trends. Scientific Journal of Polonia University, 11(4), 33-44. doi:10.23856/1103

Dabscheck, B. (1998). Book Reviews : Hans-Peter Martin and Harald Schumann (1997): The global trap: Globalization and the assault on democracy and prosperity Leichardt: Pluto Press, pp. x 269. Asia Pacific Journal of Human Resources, 36(2), 115-117. doi:10.1177/103841119803600215

Kojm, C. A. (2016). Global Change and Megatrends. Global Intelligence Oversight, 95-118. doi:10.1093/acprof:oso/9780190458072.003.0005

Padalka, O.S., Kulishov, V.V. (2015). Decentralization is a new paradigm of the socioeconomic development of Ukraine`s region. Economy of Ukraine. - №10 - p.45.

Toffler, A., Toffler, H. (2008). More Technology, Not Less. New Perspectives Quarterly, 17(3), 8-9. doi:10.1111/0893-7850.00271

Volz, U. (2011). Regional Integration, Economic Development and Global Governance. doi: $10.4337 / 9781849809153$

Yatsenko, B. P., Kiptenko V. K., Smal, V. V (2012) The global challenges of our time: social and geographical dimension. - K.: Kyiv University, - P. 3. 